\title{
Direct interaction between GluR2 and GAPDH regulates AMPAR-mediated excitotoxicity
}

\author{
Min Wang ${ }^{1}$, Shupeng Li ${ }^{1}$, Hongyu Zhang ${ }^{1}$, Lin Pei', Shengwei Zou' ${ }^{1}$, Frank J S Lee ${ }^{1}$, Yu Tian Wang ${ }^{2}$ and \\ Fang Liu ${ }^{1,3,4^{*}}$
}

\begin{abstract}
Over-activation of AMPARs (a-amino-3-hydroxy-5-methylisoxazole-4-propionic acid subtype glutamate receptors) is implicated in excitotoxic neuronal death associated with acute brain insults, such as ischemic stroke. However, the specific molecular mechanism by which AMPARs, especially the calcium-impermeable AMPARs, induce neuronal death remains poorly understood. Here we report the identification of a previously unrecognized molecular pathway involving a direct protein-protein interaction that underlies GluR2-containing AMPAR-mediated excitotoxicity. Agonist stimulation of AMPARs promotes GluR2/GAPDH (glyceraldehyde-3-phosphate dehydrogenase) complex formation and subsequent internalization. Disruption of GluR2/GAPDH interaction by administration of an interfering peptide prevents AMPAR-mediated excitotoxicity and protects against damage induced by oxygen-glucose deprivation (OGD), an in vitro model of brain ischemia.
\end{abstract}

\section{Introduction}

Glutamate is the principal excitatory neurotransmitter in the brain and is involved in numerous physiological functions including neuronal circuit development, learning and memory [1]. Glutamate-induced neurotoxicity is implicated in neuropathological disorders such as stroke and epilepsy [2]. The effects of glutamate are mediated via two major subfamilies of ligand-gated ion channels: NMDAR (N-methyl-D-aspartate receptor) and AMPAR [3]. AMPAR mediates fast synaptic transmission at excitatory synapses, while NMDAR is critical in producing a number of different forms of synaptic plasticity [1]. In neurons, mature AMPA receptors are found as tetramers consisting of various combinations of GluR1 to GluR4 subunits [4], each of which has the same topology: three transmembrane domains and one membrain re-entrant loop. All subunits are permeable to both $\mathrm{Na}^{+}$and $\mathrm{Ca}^{2+}$ ions with the exception of GluR2, which is uniquely impermeable to $\mathrm{Ca}^{2+}$. The majority of AMPA receptors in vivo contain GluR2 subunits whose ion selectivity is dominant over other subunits [5].

\footnotetext{
* Correspondence: f.liu.a@utoronto.ca

${ }^{1}$ Department of Neuroscience, Centre for Addiction and Mental Health, Toronto, Canada

${ }^{3}$ Brain Research Center, University of British Columbia, Vancouver, Canada Full list of author information is available at the end of the article
}

The accumulation of glutamate, which occurs immediately after ischemia, results in excessive stimulation of glutamate receptors and leads to neurotoxicity $[6,7]$. NMDAR-mediated neurotoxicity is dependent upon extracellular $\mathrm{Ca}^{2+}$ and is likely mediated by $\mathrm{Ca}^{2+}$ influx directly through receptor-gated ion channels [6,7]. AMPAR is also tightly associated with a selective pattern of neuronal loss in certain brain areas following both global and focal ischemia [8-20]. Similar to what is reported for NMDAR, excitotoxicity mediated by AMPAR lacking the GluR2 subunit is thought to be dependent on ion influx $\left(\mathrm{Ca}^{2+}, \mathrm{Zn}^{2+}\right)$ through AMPAR channels following agonist stimulation [19-21]. However, as most native AMPARs in the hippocampus contain the GluR2 subunit and therefore are likely impermeable to $\mathrm{Ca}^{2+}[22-26]$, it is still unclear how activation of the GluR2-containing AMPAR leads to neuronal cell death.

Protein-protein interactions with the AMPAR have been reported to affect function of AMPAR, among which the best characterized ones, such as GRIP (glutamate receptor interacting protein), ABP (AMPAR-binding protein), SAP97 (synapse-associated protein-97), PICK1 (protein interacting with C kinase-1), stargazin, NSF (N-ethylmaleimide-sensitive factor) and AP2 (adaptor protein-2) [27-34], bind to the intracellular carboxyl terminus of AMPAR. They regulate AMPAR function in a variety of ways, including modulation of AMPAR 
subcellular localization, clustering and/or trafficking. Recent studies have demonstrated that NARP (neuronal activity-regulated pentraxin) and N-cadherin interact with the amino terminus (NT) of AMPAR subunits and play an important role in AMPAR clustering [35] as well as dendritic spine formation [36]. In the present study, we have identified a new AMPAR-interacting partner, GAPDH. We show that secreted GAPDH binds specifically to the extracellular NT domain of the GluR2 subunit, a process which is promoted by AMPAR activation. Disruption of GluR2/GAPDH interaction prevents AMPAR-mediated excitotoxicity and protects against damage in OGD model.

\section{Results}

\section{GluR2 subunit directly interacts with GAPDH via its $\mathrm{Y} 142-\mathrm{K} 172$ region of $\mathrm{N}$-terminus}

To identify potential proteins that may interact with the NT domain of AMPAR subunits, we used GST-fusion proteins GST-GluR1 $1_{\mathrm{NT}}\left(\mathrm{A}_{19}-\mathrm{E}_{538}\right)$ and GST-GluR2 $2_{\mathrm{NT}}$ $\left(\mathrm{V}_{22}-\mathrm{E}_{545}\right)$ to affinity "pull-down" proteins from solubilized rat hippocampal tissues along with GST alone as a control. The precipitated proteins were then identified by Coomassie brilliant blue staining following SDS-PAGE. A prominent protein band of $\sim 37 \mathrm{kD}$ was specifically precipitated by GST-GluR2 $2_{\mathrm{NT}}$, but not by GST alone or GST-GluR1 $1_{\mathrm{NT}}$ (Figure 1A). Mass spectrometry analysis (LC-MS/MS, Protana [now Transition Therapeutics]) of this protein band identified three fragments that were homologous to and covered $17 \%$ of the sequences within rat GAPDH (VIISAPSADAPMFVM GVNHEK; VIHDNFGIVEGLMTTVHAITATQK; VPTP NVSVVDLTCR). These results suggested that the GluR2 subunit might form a protein complex with GAPDH through its NT domain. We then confirmed the GluR2/GAPDH interaction with affinity purification experiments using GST-GluR2 $2_{\mathrm{NT}}$, GST-GluR2 $2_{\mathrm{CT}}\left(\mathrm{I}_{833-}\right.$ $\mathrm{I}_{883}$ ) and GST alone. Subsequent Western blot analysis using a GAPDH antibody confirmed the association between GAPDH and GluR2 $2_{\mathrm{NT}}$, but not GluR2 $2_{\mathrm{CT}}$ (Figure 1B).

Before conducting further experiments, we examined whether GluR2/GAPDH complex exists in vivo. As shown in Figure 1C, the GluR2 antibody was able to coimmunoprecipitate (Co-IP) GAPDH from solubilized proteins extracted from rat hippocampal tissues confirming the in vivo association between GluR2 and GAPDH. In order to smooth the way for the following functional studies, three GluR2 $2_{\mathrm{NT}}$ GST-fusion proteins (GluR2 $2_{\mathrm{NT} 1}$ : $\mathrm{V}_{22}-\mathrm{S}_{271}$, GluR2 $2_{\mathrm{NT2}}: \mathrm{K}_{272}-\mathrm{I}_{421}$, GluR2 $\left.2_{\mathrm{NT} 3}: \mathrm{L}_{422}-\mathrm{E}_{545}\right)$ were constructed (Figure 1D) and utilized in affinity purification experiments to delineate the region (s) of GluR2 ${ }_{\mathrm{NT}}$ involved in the interaction with GAPDH. As shown in Figure 1E, GST-GluR2 $2_{\mathrm{NT} 1}$, but not GST-GluR2 $2_{\mathrm{NT} 2}$, GST-GluR2 $2_{\mathrm{NT} 3}$ or GST alone, precipitated GAPDH indicating that the GluR2 subunit interacts with GAPDH through its NT region $\mathrm{V}_{22}-\mathrm{S}_{271}$. A series of truncations of the GluR2 $2_{\mathrm{NT} 1}$ region were then created to map the site that interacts with GAPDH (Figure 1D). As shown in Figure $1 \mathrm{~F}$ and $1 \mathrm{G}$, GST-GluR2 $\mathrm{NT1}_{1-3}\left(\mathrm{H}_{122}-\mathrm{K}_{172}\right)$ and GST-GluR2 $2_{\text {NT1-3-2 }}\left(\mathrm{Y}_{142}-\mathrm{K}_{172}\right)$ were able to precipitate GAPDH from rat hippocampal tissues.

While these results suggested the existence of the GluR2/GAPDH complex, it did not clarify whether this GluR2/GAPDH complex was formed through either a direct interaction or was mediated indirectly by other accessory binding proteins. Therefore we performed in vitro binding assays to examine whether GAPDH and the GluR2 subunit directly interact with each other. As shown in Figure $1 \mathrm{H}$, in vitro translated $\left[{ }^{35} \mathrm{~S}\right]-\mathrm{GAPDH}$ probe bound with GST-GluR2 $2_{\mathrm{NT} 1}$ but not with GSTGluR2 $2_{\mathrm{NT} 2}$, GST-GluR2 $2_{\mathrm{NT} 3}$ or GST alone, indicating the specificity of the direct protein-protein interaction between GAPDH and GluR2 $2_{\mathrm{NT} 1}$. Consistent with the results from affinity purification experiments, the in vitro translated $\left[{ }^{35} \mathrm{~S}\right]$-GAPDH probe only hybridized with GST-GluR2 $2_{\mathrm{NT1} 1-3}$ and GST-GluR2 $2_{\mathrm{NT1}-3-2}$, (Figure 1I, J). Together, these data provided in vitro evidence that GAPDH forms a direct protein-protein interaction with the GluR2 subunit through the $\mathrm{Y}_{142}-\mathrm{K}_{172}$ region of the GluR2 $2_{\mathrm{NT}}$.

\section{Agonist-facilitated GluR2/GAPDH complex formation occurs extracellularly}

As the NT region of GluR2 locates extracellularly, we then investigated whether the GluR2/GAPDH interaction occurs extracellularly by performing cell surface biotinylation experiments in primary culture of rat hippocampus, in which cell surface proteins of neurons were labeled with sulfo-NHS-LC-biotin. As shown in Figure 2A, the GluR2 antibody precipitated GAPDH from the biotinylated (B, cell surface) fraction, but failed to pull down GAPDH from the non-biotinylated (NB, intracellular) fraction, suggesting that the GluR2/GAPDH complex formation occurs extracellularly. Consistent with our findings, a previous study demonstrated that GAPDH was constitutively secreted into the extracellular space in several mammalian cell lines including HEK-293 T cells and neuro-2a cells [37]. We therefore speculated that GAPDH might be secreted into the extracellular space and form a protein complex with GluR2 $2_{\mathrm{NT}}$. To test our hypothesis, we first confirmed GAPDH secretion in our cell lines by immunoprecipitating GAPDH from the conditioned medium (incubation with neurons/cells for 24 hours) of hippocampal primary cultures with a primary antibody against GAPDH. As shown in Figure 2B, GAPDH was immunoprecipitated from conditioned medium, but not from fresh medium. To further exclude the possibility that the observed 


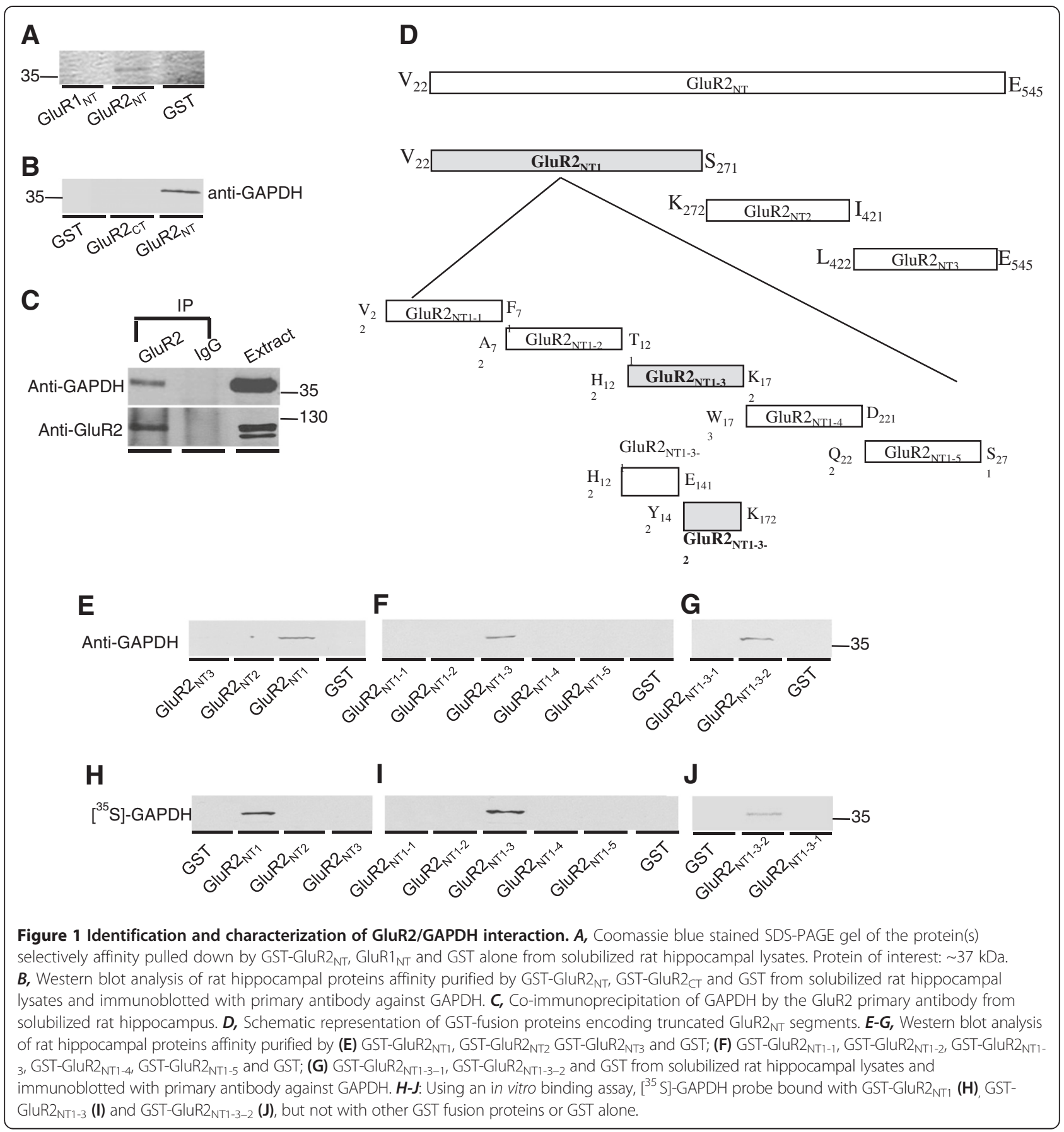

GAPDH in the conditioned medium resulted from cell lysis, conditioned media from non-transfected HEK$293 \mathrm{~T}$ cells and from cells expressing GluR1/2 subunits were collected, concentrated and examined by Western blot analyses using anti-GAPDH and anti- $\alpha$-tubulin antibodies. As shown in Figure $2 \mathrm{C}$, regardless of GluR1/2 subunit expression, GAPDH was detected from both conditioned media and cell lysates, whereas $\alpha$-tubulin (a cytoplasmic protein marker) was only detected from cell lysates, indicating that the GAPDH found in the conditioned medium is secreted from cells and is not a contaminant due to cell lysis.

Furthermore, we examined the effect of the AMPAR activation on the formation of GluR2/GAPDH complex. By conducting Co-IP experiments, we found that AMPAR activation with either $100 \mu \mathrm{M}$ glutamate in HEK-293 T cells expressing GluR1/2 subunits or $100 \mu \mathrm{M}$ kainic acid (KA) in hippocampal neurons facilitated the 

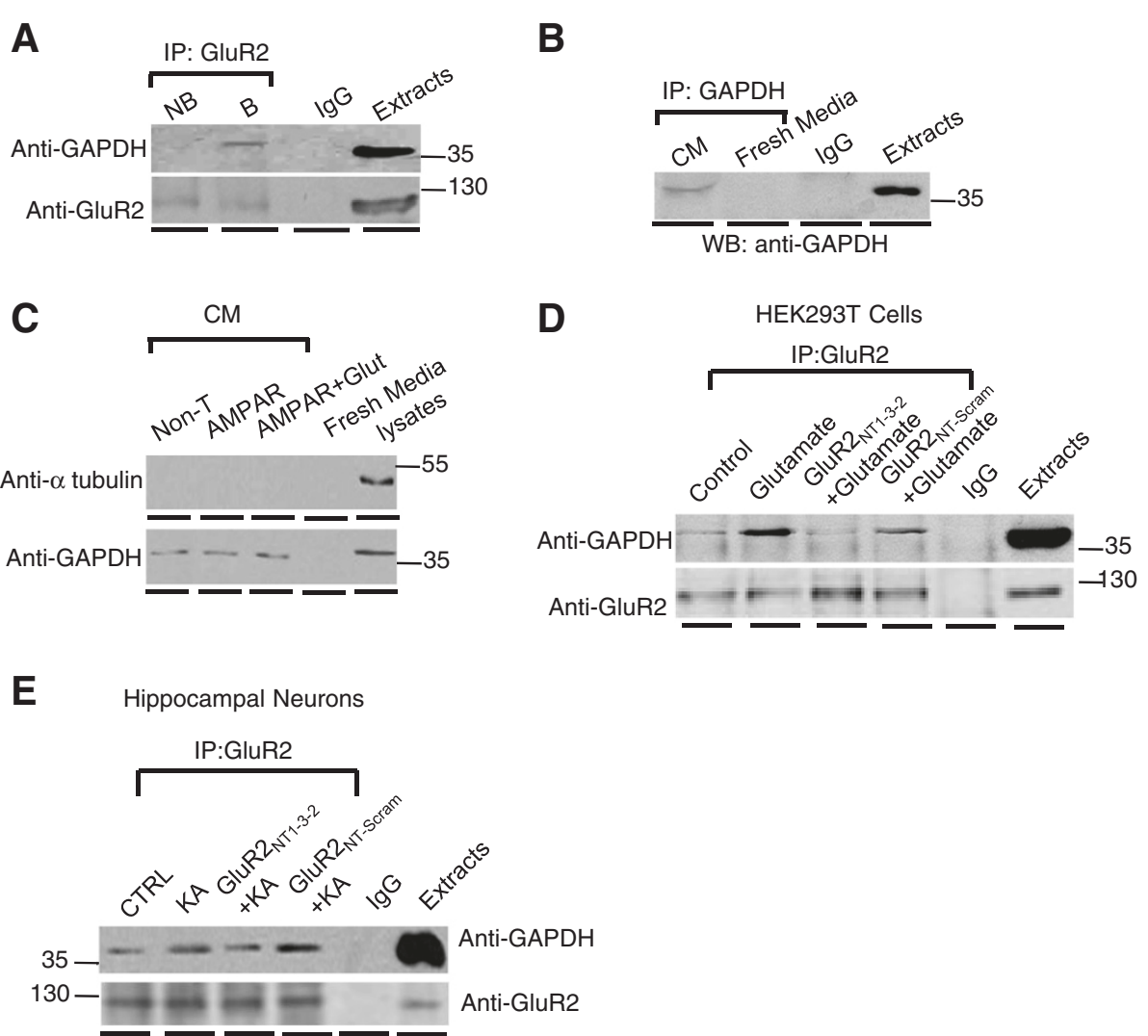

Figure 2 GluR2/GAPDH interaction occurs extracellularly. $\boldsymbol{A}$, Rat hippocampal neurons were incubated with sulfo-NHS-LC biotin to label cell surface proteins. GAPDH that co-immunoprecipitated with GluR2 antibody was examined in both non-biotinylated (NB) and biotinylated (B) proteins. $\boldsymbol{B}$, Using a rabbit anti-GAPDH antibody, GAPDH was immunoprecipitated from the conditioned medium (CM; medium incubated with neurons/cells for 24 hours) of primary cultures of rat hippocampus but not from fresh medium. A mouse GAPDH antibody was used for Western blotting and rabbit lgG was used as negative control. C, Western blot analysis of GAPDH and a-tubulin in concentrated conditioned medium of non-transfected HEK-293 T cells (non-T) and HEK-293 T cells transfected with GluR1/2 subunits (AMPAR), in the presence or absence of glutamate (AMPAR + Glut). Cell lysates were used as controls. D-E: Coimmunoprecipitation of GAPDH by primary antibody against GluR2 subunit (with or without glutamate treatment) from HEK-293 T cells expressing GluR1/2 subunits (D) and hippocampal neurons (E) pre-treated with GluR2NT1-3-2 or GluR2 NT1-3-2-scram peptides (top panels). Each Coimmunoprecipitation was in parallel with Western blot analysis of the directly immunoprecipitated proteins (bottom panels). All western blot analysis and co-immunoprecipitation assays in this figure are representative of at least 3 independent experiments.

GluR2/GAPDH complex formation by $75 \pm 18 \%$ and $58 \pm 11 \%$ (mean \pm SEM, $n=3$ ), respectively (Figure $2 \mathrm{D}, \mathrm{E}$; top panels). In each Co-IP experiment, $500 \mu \mathrm{g}$ of protein were incubated in the presence of primary antibodies anti-GluR2 or rabbit IgG, and $50 \mu \mathrm{g}$ of extracted protein was used as positive control. The level of directly immunoprecipitated GluR2 subunit was not significantly altered by the agonist stimulation (Figure 2D, E; bottom panels). If the GluR2 $2_{\mathrm{NT} 1-3-2}$ region is essential for GluR2 to interact with GAPDH, application of the peptide encoding GluR2 $2_{\mathrm{NT} 1-3-2}$ would disrupt the GluR2/GAPDH interaction by competing with GluR2 for GAPDH. As expected, pre-incubation of the GluR2 $2_{\mathrm{NT} 1-3-2}$ peptide (10 $\mu \mathrm{M}, 1$ hour), but not the scrambled GluR2 $2_{\mathrm{NT} 1-3-2}$ peptide (GluR2 $2_{\text {NT1-3-2Scram }}$ ), significantly inhibited the agonist-induced increase of the GluR2/GAPDH complex formation in transfected HEK-293 T cells (Figure 2D, $65 \pm 8 \%$ decrease; mean $\pm \mathrm{SE}, \mathrm{n}=3$ ) and in hippocampal neurons (Figure 2E, $46 \pm 6 \%$ decrease; mean $\pm S E, n=3$ ). The fact that extracellular application of the interfering GluR2 ${ }_{\text {NT1-3-2 }}$ peptide was able to disrupt the GluR2/ GAPDH interaction further supports the notion that the GluR2/GAPDH complex formation occurs extracellularly.

\section{Disruption of GluR2/GAPDH interaction inhibits AMPAR-mediated excitotoxicity}

Both AMPAR and GAPDH have been independently shown to be involved in cell toxicity [38-42]. The observation that AMPAR activation promoted GluR2/GAPDH complex formation suggested that the GluR2/GAPDH interaction might be involved in AMPAR-mediated excitotoxicity. Before conducting further experiments, we first confirmed the 
ability of glutamate (300 $\mu \mathrm{M}, 24$ hour; plus $25 \mu \mathrm{M}$ cyclothiazide to prevent AMPAR desensitization) to induce cell death in HEK-293 T cells expressing GluR1/2 (Figure $3 \mathrm{~A}$ ), which is consistent with previous studies $[43,44]$. To investigate the role of the GluR2/GAPDH interaction in AMPAR-mediated cell death, HEK-293 T cells expressing GluR1/2 were pre-treated with the GluR2 $2_{\text {NT1-3-2 }}$ peptide $(10 \mu \mathrm{M}, 1$ hour $)$, which is able to disrupt the GluR2/GAPDH association (confirmed in Figure 2D). As shown in Figure 3B, pre-incubation with the GluR2 $2_{\mathrm{NT} 1-3-2}$ peptide significantly attenuated glutamate-induced $(300 \mu \mathrm{M}, 500 \mu \mathrm{M})$ cell death. The
GluR2 $2_{\text {NT1-3-2 }}$ peptide itself showed no effect in either the absence of glutamate treatment (Figure $3 \mathrm{~B}$ ) or in non-transfected cells regardless of glutamate treatment (Figure $3 \mathrm{C}$ ). The specificity of the GluR $2_{\mathrm{NT} 1-3-2}$ peptide was also confirmed in HEK-293 $\mathrm{T}$ cells expressing GluR1/3, GluR1/4 or GluR3/4 subunits, where pre-incubation with the GluR2 $2_{\mathrm{NT} 1-3-2}$ peptide failed to inhibit AMPAR-mediated cell death (Figure 3D).

To study the GluR2/GAPDH interaction in a relevant cellular milieu, rat hippocampal neurons were utilized in parallel experiments. We previously confirmed in Figure 2E
A

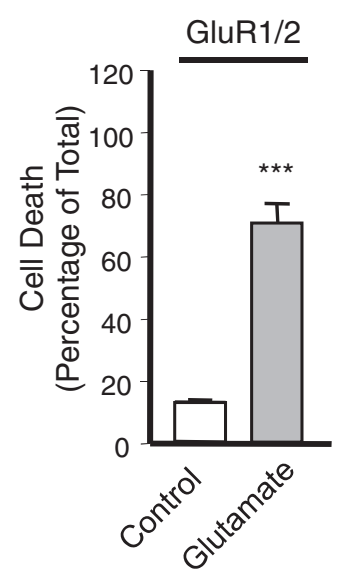

C

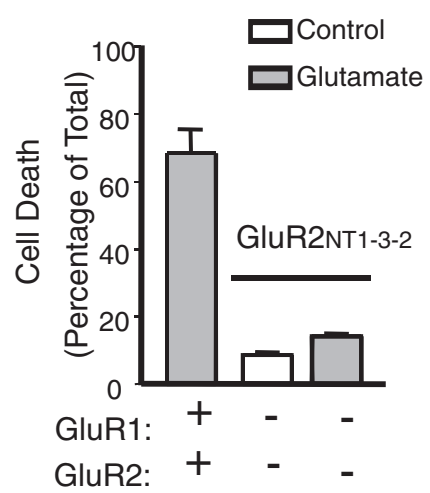

B

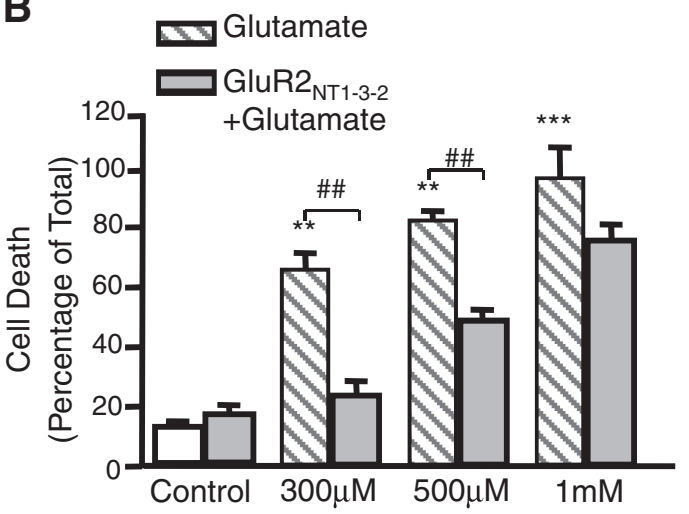

D

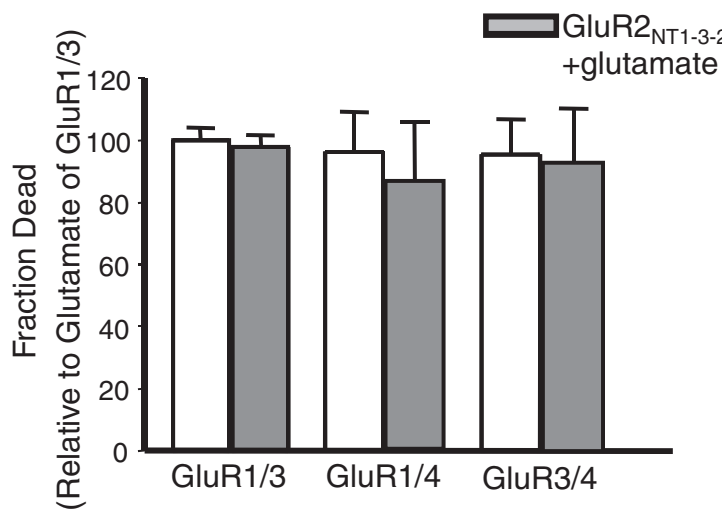

Figure 3 Regulation of the AMPAR-mediated cell death in transfected cells. $\boldsymbol{A}$, Bar graph summarizing the quantitative measurements of PI

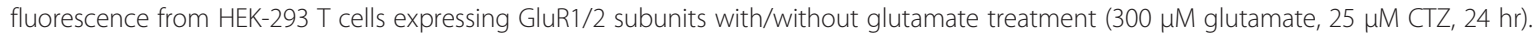
***Significantly different from control group $(P<0.001, n=9$ per group), t-test. $\boldsymbol{B}$, Bar graph summarizing the quantitative measurements of PI fluorescence from HEK-293 T cells expressing GluR1/2 subunits with/without glutamate treatment at various doses in the presence/absence of GluR2 $2_{\text {NT1-3-2 }}$ peptide (10 $\left.\mathrm{MM}, 1 \mathrm{hr}\right) .{ }^{* *},{ }^{* * *}$ Significantly different from control group $(P<0.01,0.001)$, ANOVA followed by post-hoc SNK test; \#\#, significant from the corresponding glutamate group $(P<0.01, \mathrm{n}=9$ per group), t-test. $\boldsymbol{C}$, Bar graph summarizing the quantitative measurements of PI fluorescence from non-transfected HEK-293 T cells or HEK-293 T cells expressing GluR1/2 subunits. Cells were pre-treated with the GluR2 ${ }_{\text {NT1-3-2 }}$ peptide with/without glutamate treatment ( $n=9$ per group). $\boldsymbol{D}$, Bar graph summarizing the quantitative measurements of PI fluorescence from HEK-293 T cells expressing GluR1/3, GluR1/4 or GluR3/4 subunits with glutamate treatment in the presence/absence of the GluR2 ${ }_{\mathrm{NT} 1-3-2}$ peptide ( $n=9$ per group). All PI fluorescence measurement assays were performed 3 times independently. 
that pre-incubating hippocampal neurons with the GluR2 $2_{\text {NT1-3-2 }}$ peptide interrupted the GluR2/GAPDH interaction promoted by the AMPAR activation. Thus, we examined whether the disruption of this interaction in hippocampal neurons by applying the GluR2 $2_{\mathrm{NT} 1-3-2}$ peptide would rescue neurons from AMPAR-mediated excitotoxicity. AMPAR-mediated cell death was induced by treating neurons with KA $(100 \mu \mathrm{M}, 1$ hour $)$ in the presence of NMDAR and $\mathrm{Ca}^{2+}$ channel antagonists (10 $\mu \mathrm{M}$ MK-801 and $2 \mu \mathrm{M}$ nimodipine). As shown in Figure $4 \mathrm{~A}$, pretreatment with the GluR2 $2_{\mathrm{NT} 1-3-2}$ peptide significantly inhibited AMPAR-mediated cell death.

AMPAR-mediated toxicity is often considered a contributing, if not an underlying, causative factor in ischemia, which deprives brain cells of glucose and oxygen, causing irreversible brain damage within minutes. Cells in ischemic brain tissue undergo a number of changes: they rapidly lose their energy supplies, their membranes become depolarized, calcium loads are increased, reactive oxygen types are produced and excitotoxic effects are found. These biochemical changes are followed by irreversible changes to cellular structures and cell death. The oxygen glucose deprivation (OGD) cell lesion model represents a valid simulation of the conditions in brain ischemia $[45,46]$. Therefore, we assessed the effectiveness of the GluR2 $2_{\text {NT1-3-2 }}$ peptide to rescue cells from neurotoxic stress in the OGD model to verify the implication of the GluR2/GAPDH interaction in ischemia. As shown in Figure $4 \mathrm{~B}$, the GluR2 $2_{\mathrm{NT} 1-3-2}$ peptide pretreatment (10 $\mu \mathrm{M}, 1$ hour) was able to significantly attenuate OGD-induced cell death $(30.4 \% \pm 9.5 \%)$ in the presence of $10 \mu \mathrm{M} \mathrm{MK}-801$ and $2 \mu \mathrm{M}$ nimodipine.

In order to further confirm the role of GAPDH in the AMPAR-mediated cell death, GAPDH siRNA was transfected into HEK-293 T cells to block the expression of GAPDH, but not the expression of GluR2 (Figure 4C). As shown in Figure 4D-E, AMPAR-mediated cell death was significantly attenuated in the presence of GAPDH siRNA. Together, these data suggest that the GluR2/ GAPDH interaction may play a critical role in the GluR2-contaning AMPAR-mediated cell death.

\section{Activation of AMPAR induces AMPAR/GAPDH complex internalization through the GluR2/GAPDH interaction}

Previous studies demonstrated that agonist stimulation could induce AMPAR endocytosis [47-49]. Thus, we examined whether the extracellular GAPDH would internalize along with AMPAR through the GluR2/GAPDH interaction upon the activation of AMPAR. To quantify GluR2 and GAPDH cell surface levels in HEK-293 T cells expressing GluR1/2, a cell-based ELISA assay was applied as previously described $[49,50]$. We first confirmed the results from previous studies that the glutamate stimulation
(100 $\mu \mathrm{M}, 30$ minutes) induced a significant decrease in plasma membrane GluR2 (Figure 5A). We then tested whether the cell surface-associated GAPDH is also decreased upon agonist stimulation of AMPAR. As shown in Figure 5B, activation of AMPAR significantly decreased the cell surface-associated GAPDH in HEK-293 $\mathrm{T}$ cells expressing GluR1/2, a phenomena that can be abolished by the pre-treatment of GluR $2_{\text {NT1-3-2 }}$ peptide. These data, together with the inability of glutamate stimulation to internalize the cell surface-associated GAPDH in the non-transfected HEK-293 $\mathrm{T}$ cells (Figure 5C) or HEK-293 $\mathrm{T}$ cells transfected with GluR1/3 subunits (Figure 5D), suggest that GAPDH internalization may be a passive process enabled by the GluR2/GAPDH interaction.

To further investigate whether the observed GAPDH internalization is dependent on the GluR2 internalization, we tested whether blockade of GluR2 endocytosis will inhibit GAPDH internalization. Previous studies demonstrated that GluR2 endocytosis is dynamin-dependent and that the expression of the dominant-negative dynamin mutant (K44E) was able to block the GluR2 internalization $[47,49]$. Thus, after confirming the ability of the K44E mutant to block the GluR2 internalization (Figure 5E), we examined whether the K44E mutant affected cell surfaceassociated GAPDH internalization in HEK-293 T cells expressing GluR1/2 subunits. As shown in Figure 5F, the K44E mutant significantly inhibited glutamate-induced cell surface-associated GAPDH internalization, indicating that GAPDH internalized through a dynamin-dependent pathway and further confirmed that GAPDH was cointernalize with the GluR2 subunit. Moreover, the K44E mutant also attenuated glutamate-induced cell death in HEK-293 T cells expressing GluR1/2 subunits (Figure 5G), indicating that GluR2/GAPDH complex internalization may play an important role in the GluR2-containing AMPAR-mediated cell death.

\section{Discussion}

AMPAR-mediated excitotoxicity has been implicated in the pathogenesis of neuronal loss associated with a number of brain disorders, including transient forebrain ischemia [8-20]. However, the underlying mechanisms remain unclear. An uncontrollable rise in intracellular $\mathrm{Ca}^{2+}$ and $\mathrm{Zn}^{2+}$, with subsequent activation of diverse downstream cell death signals has been one of the most prominent hypotheses to explain excitotoxic neuronal death [19,20,51-55]. Although GluR2-containing AMPARs are calcium impermeable, recent studies have suggested that selective reductions in the expression of GluR2, resulting in an increase in $\mathrm{Ca} 2+$-permeable AMPA receptors, have been associated with an increased vulnerability of neurons to ischemic injury [16,56-61]. Although the mechanisms involved are not fully understood, it has been 
A

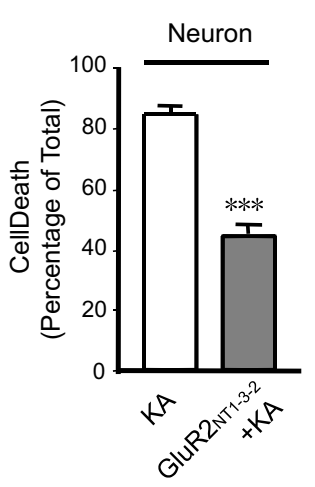

C

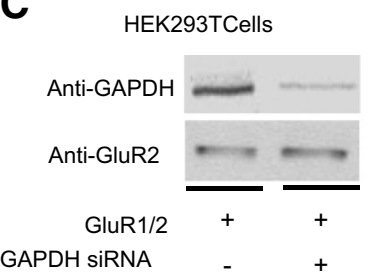

D

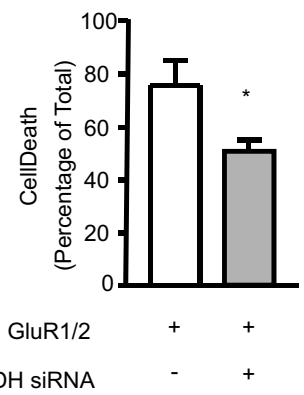

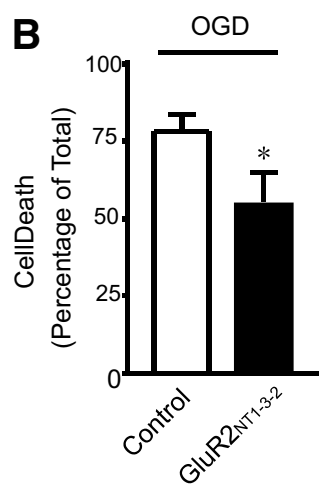

E

Propidium iodide Staining of HEK 293T Cells

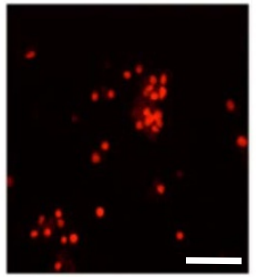

GluR1/GluR2

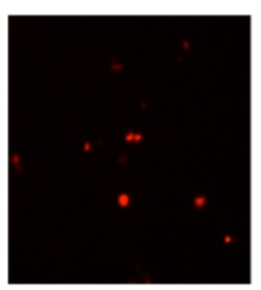

GluR1/GluR2+ GAPDH siRNA

Figure 4 Regulation of the AMPAR-mediated cell death in cultured neurons and OGD model. $A$, Bar graph summarizing the quantitative measurements of PI fluorescence from rat hippocampal primary culture with KA treatment (100 $\mu \mathrm{M}, 1 \mathrm{hr})$ in the presence/absence of the GluR2NT1-3-2 peptide. ${ }^{* *}$ Significantly different from KA group $(P<0.001, n=9$ per group), t-test. $\boldsymbol{B}$, Bar graph summarizing the quantitative measurements of PI fluorescence from rat hippocampal primary culture with OGD protocol in the presence/absence of the GluR2 $2_{N T 1-3-2}$ peptide. *Significantly different from OGD group ( $P<0.05, n=9$ per group), t-test. $C$, Western blot analysis of GAPDH (upper panel) and GluR2 (lower panel) expression in HEK 293 T cells expressing GluR1/2 subunits in the presence/absence of the GAPDH siRNA. $\boldsymbol{D}$, Bar graph summarizing the quantitative measurements of PI fluorescence from HEK-293 T cells expressing GluR1/2 subunits with glutamate treatment in the presence/ absence of the GAPDH siRNA ( $P<0.05, \mathrm{n}=9$ per group), t-test. $\boldsymbol{E}$, Propidim iodide positive cells (red) from HEK-293 T expressing GluR1/2 subunits with glutamate treatment in the presence/absence of the GAPDH siRNA, scale bar $50 \mu \mathrm{m}$. All PI fluorescence measurement assays were performed 3 times independently.

suggested that GluR2 internalization may enhance the $\mathrm{Ca}^{2+}$ influx that results in neurotoxicity, either through newly synthesized $\mathrm{Ca}^{2+}$-permeable AMPARs [57] or by activation of a caspase-dependent apoptotic pathway [62]. Consistent with previous studies, our data has shown that agonist stimulation of AMPAR results in the internalization of GluR2 and promotes extracellular GAPDH internalization via a GluR2/GAPDH coupling-dependent process. This is the first evidence showing that the N-terminal of the GluR2 subunit plays an important role in AMPA receptormediated excitotoxicity through regulating AMPAR trafficking. Many studies have shown that agonist- induced GluR2 internalization is a dynamin-dependent process $[47,49]$. The observations of our study that mutant dynamin abolishes both GluR2 and GAPDH internalization and the inability of GAPDH to internalize in cells lacking GluR2 suggest that GAPDH internalization is a passive process facilitated by the GluR2/GAPDH interaction and mediated by GluR2 internalization.

Given the fact that GAPDH interacts with the extracellular NT of GluR2, it is likely that the GluR2/GAPDH protein complex may be in an endocytosed vesicle following the agonist-induced internalization. On this basis it would be logical to further ask how the GluR2/GAPDH complex gets 


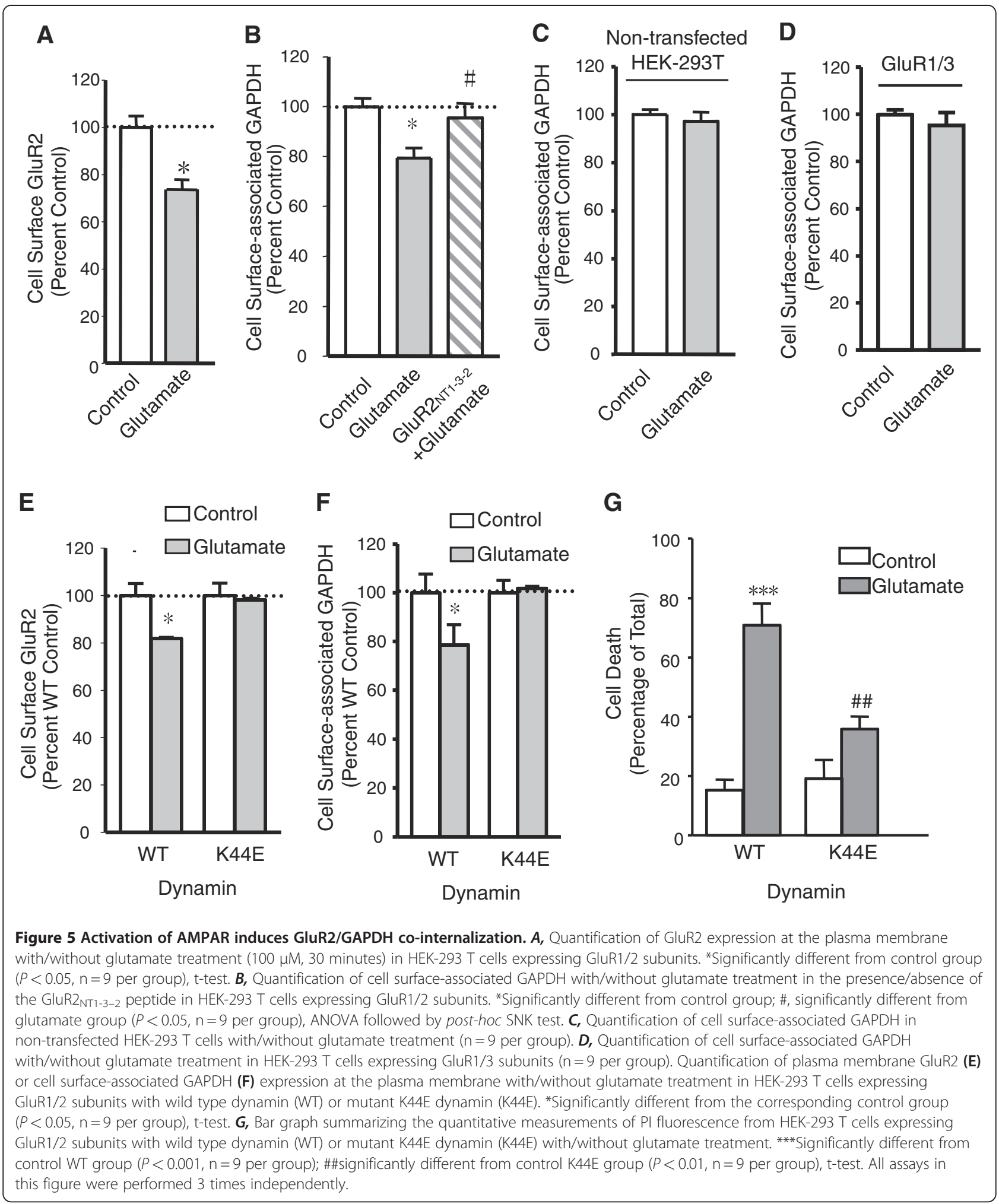

out of the vesicle and promotes excitotoxic neuronal death. There are many possibilities for this question. First, the complex may be transported to the nucleus via a retrograde vesicle transport mechanism leading to the fusion of the vesicle with ER or nuclear membranes or via mechanisms recently proposed for the nuclear translocation of another plasma membrane receptor, the EGF receptor [63,64]. Second, the GluR2/GAPDH complex formation in the 
vesicle may lead to the activation of lysosome in the vesicle that breaks the vesicle and release the GluR2/ GAPDH into the cytoplasm.

The possible mechanisms that underlie this GluR2/ GAPDH related cell death is particularly interesting. It is somewhat surprising to find that the AMPAR-mediated cell death involves GAPDH, a key enzyme involved in glycolysis with a ubiquitous intracellular distribution. However, additional roles for GAPDH have been discovered recently, including membrane fusion/transport, binding to low molecular weight $\mathrm{G}$ proteins, regulation of the cytoskeleton, accumulation of glutamate into presynaptic vesicles, and apoptosis [65-71]. Recent studies have shown that GAPDH binds to Siah1 and triggers apoptosis [39]. Moreover GAPDH has also been reported to interact with p53 [72], a tumor suppressor and transcription factor that has been implicated in glutamatemediated excitotoxicity [73-75]. Numerous evidence show that activation of p53 can trigger apoptosis (for reviews, see [76]) under conditions of cellular stress mediated by phosphorylation or acetylation of p53 [77]. Whether Siah1, p53 or other molecules are involved in GluR2/GAPDHrelated cell death pathway requires much more additional work for a better understanding of the detailed molecular mechanisms.

Stroke is the second leading cause of death worldwide yet there are very few effective pharmacological treatments for patients suffering ischemic stroke. Thrombolytics such as alteplase and tenecteplase have been a significant advance in the treatment of ischemic stroke. However, thrombolytics must be given soon after a stroke to be effective (within 3 hours of ischemic episode). This short time frame has limited their use in many situations. There continues to be a significant unmet need for acute pharmacological treatments beyond thrombolytics. Advances in recent years include hypothermia [78-80], oxygen therapy [81], stem cell transplantation [82] and cerebral plasticity stimulation (trophic factor) strategies [83]. These novel techniques are intriguing, but will require further well-designed prospective trials to assess clinical feasibility, safety, and efficacy [84]. Another approach that has received considerable attention is agents that inhibit ischemia-induced excitotoxicity though directly blocking glutamate receptors. However, all have failed at various stages of development for a variety of reasons. One of the main drawbacks of the glutamate receptor antagonists is that they block normal excitatory neurotransmission necessary for maintaining basic brain functions. For this reason, much research has been directed at identifying drugs and peptides that may be able to selectively target protein-protein interactions that have more narrow function than a certain neurotransmitter receptor. In the present study, we have shown that administration of the interfering $\mathrm{GluR2} 2_{\mathrm{NT} 1-3-2}$ peptide to interrupt the GluR2/GAPDH interaction significantly mitigates neuronal cell death in a cell model of ischemia, revealing a previously unappreciated signaling pathway underlying AMPAR-mediated excitotoxicity and it may provide a new avenue for the development of a complementary therapeutics in the treatment of neuropathological disorders, such as stroke and epilepsy.

\section{Materials and methods}

\section{Cell culture and transient transfection}

HEK293 T cells were cultured in $\alpha$-MEM (Invitrogen, Carlsbad, CA) supplemented with $10 \%$ fetal bovine serum (Invitrogen) and maintained in incubators at $37^{\circ} \mathrm{C}, 5 \%$ CO2. HEK293T cells were transiently transfected with plasmid constructs and/or siRNA using lipofectamine 2000 reagents (Invitrogen). Cells were harvested 48 hours post transfection.

\section{Primary hippocampal neuron culture and OGD treatment} Primary cultures from hippocampus were prepared from fetal Wistar rats (embryonic day 17-19) on Cell + (Sarstedt) culture dishes as previously described [85-87]. The cultures were used for experiments on 12-15 days after plating. Hippocampal cultures were pretreated GluR2 $2_{\mathrm{NT1}-3-2}$ peptides prior to kainic acid treatment. OGD treatment was performed in the presence of MK-801 and nimodipine as previously described [57].

\section{GST fusion proteins}

To construct GST-fusion proteins encoding truncated GluR2 and GAPDH, cDNA fragments were amplified by using PCR method with specific primers. Except where specified, all $5^{\prime}$ and $3^{\prime}$ oligonucleotides incorporated BamH1 site (GGATCC) and Xho1 sites (CTCGAG), respectively, to facilitate subcloning into vector pGEX-4T3 (for GST-fusion protein construction). GST-fusion proteins were prepared from bacterial lysates with Glutathione Sepharose 4B beads as described by the manufacturer (Amersham). To confirm appropriate splice fusion and the absence of spurious PCR generated nucleotide errors, all constructs were resequenced.

\section{Protein affinity purification, in vitro binding, co-immunoprecipitation and western blot}

Protein affinity purification, in vitro binding, co-immunoprecipitation and Western blot analyses were performed as previously described [85-87]. Antibodies used for immunoprecipitation, Western blots and cell surface ELISA assays include GAPDH (polyclonal from Abcam, monoclonal from Chemicon), GluR2 (Western blots: Chemicon; immunoprecipitation: Upstate), and $\alpha$-tubulin (monoclonal, Sigma-Aldrich). 


\section{Cell-ELISA assays}

HEK-293 T cells transfected with plasmid constructs were treated with $100 \mu \mathrm{M}$ glutamate or extracellular solution (ECS) before fixing in $4 \%(\mathrm{~W} / \mathrm{V})$ paraformaldehyde for 10 minutes in the absence (non-permeabilized conditions) or presence (permeabilized conditions) of $1 \%(\mathrm{~V} / \mathrm{V})$ Triton $\mathrm{X}-100$. Cells were incubated in $1 \%(\mathrm{~W} / \mathrm{V})$ glycine for 10 minutes at $4^{\circ} \mathrm{C}$ to recover from the fixing. Cells were then incubated with specific primary antibodies for the purpose of labeling the receptors or proteins on the cell surface under non-permeabilized conditions or the entire receptor pool under permeabilized conditions. After incubation with corresponding HRP-conjugated secondary antibodies (Sigma-Aldrich), the HRP substrate o-phenylenediamine (Sigma-Aldrich) was added to produce a color reaction that was stopped with the equal volume of $3 \mathrm{~N} \mathrm{HCl}$. Fluorescence intensity in each well was measured with a plate reader (Victor3; PerkinElmer). The cell surface expression of HA-GluR2 after pre-treatment with glutamate was presented as the ratio of colorimetric readings under non-permeabilized conditions to those under permeabilized conditions, and then normalized to their respective control groups (pretreated with ECS). Afterwards, cells were scrapped from the dishes, and the protein concentration of each dish was measured. The results of cell surface expression of receptors or proteins were calibrated by the protein concentration of each well. Analysis was done using at least 9 separate wells in each group. Cell ELISA using primary hippocampal neurons was performed identically with assays using HEK-293 T cells, with the exception that the anti-GluR2 antibody (MAB397; Chemicon) was used as primary antibody instead of anti-HA.

\section{Quantification of AMPAR-mediated excitotoxicity}

HEK-293 T cells transfected with GluR1/2 subunits were exposed to $300 \mu \mathrm{M}$ glutamate $/ 25 \mu \mathrm{M}$ cyclothiazide at $37^{\circ} \mathrm{C}$ for 24 hour. Cells were allowed to recover for 24 hours at $37^{\circ} \mathrm{C}$. To quantify AMPAR-mediated cell death, culture medium was replaced by extracellular solution containing $50 \mu \mathrm{g} / \mathrm{ml}$ of propidium iodide (PI) (Invitrogen, Carlsbad, CA). After 30 minutes incubation at $37^{\circ} \mathrm{C}$, fluorescence intensity in each well was measured with a plate reader (Victor3; PerkinElmer, Waltham, MA). The fraction of dead cells was normalized to the total cell number. Primary hippocampal neurons were exposed to $100 \mu \mathrm{M}$ $\mathrm{KA} / 25 \mu \mathrm{M}$ cyclothiazide in the presence of NMDAR and $\mathrm{Ca}^{2+}$ channel antagonists $(10 \mu \mathrm{M}$ MK-801 and $2 \mu \mathrm{M}$ nimodipine, respectively) at $37^{\circ} \mathrm{C}$ for 1 hour.

\section{Cell biotinylation}

For cell surface biotinylation, cells were rinsed four times with ice-cold $\mathrm{PBS}^{2+}$ (PBS containing $0.1 \mathrm{mM} \mathrm{CaCl}_{2}$ and $1.0 \mathrm{mM} \mathrm{MgCl}_{2}$ ) after treatment, and incubated twice with $1.0 \mathrm{mg} / \mathrm{ml}$ sulfo-NHS-LC-biotin (Pierce, Rockford, IL) for 20 minutes at $4^{\circ} \mathrm{C}$. Non-reactive biotin was quenched by 20 minutes incubation at $4^{\circ} \mathrm{C}$ in ice-cold $\mathrm{PBS}^{2+}$ and $0.1 \mathrm{M}$ glycine. Cells were solubilized in RIPA buffer $(10 \mathrm{mM}$ Tris, ph7.4, $150 \mathrm{mM} \mathrm{NaCl}, 1.0 \mathrm{mM}$ EDTA, $0.1 \%(\mathrm{~W} / \mathrm{V})$ SDS, $1.0 \%(\mathrm{~V} / \mathrm{V})$ Triton $\mathrm{X}-100$ and $1.0 \%(\mathrm{~V} / \mathrm{V})$ Sodium deoxycholate) containing protease inhibitors $(1.0 \mathrm{mM}$ PMSF and $1.0 \mu \mathrm{g} / \mathrm{ml}$ protease cocktail). Biotinylated and non-biotinylated proteins were separated from equal amounts of cellular protein by incubation with $50 \mu \mathrm{l}$ of $50 \%$ slurry of immobilized streptavidin-conjugated beads (Pierce, Rockford, IL) overnight with constant mixing at $4^{\circ} \mathrm{C}$. Unbound proteins (supernatant) were saved for later co-immunoprecipitation experiment. Proteins bound to streptavidin beads were eluted in biotin elution buffer. Biotinylated and non-biotinylated samples were applied to protein A/G PLUS-agarose (Santa Cruz Biotechnology, Santa Cruz, CA) for co-immunoprecipitation.

\section{Competing Interest}

The authors declare that they have no competing interests.

\section{Acknowledgments}

We gratefully acknowledge Mr. Brian Vukusic for technical assistance. We thank Dr. Paul Talyor for help with the MS experiments and analysis. We thank Dr. Qi Wan for providing the OGD cell model. F.L. is a recipient of Career Investigator Award of the Heart and Stroke Foundation of Canada. S.P. $L$. is a recipient of post-doctoral fellowship of the Heart and Stroke Foundation of Canada. The work is supported by operating grant from Heart and Stroke Foundation of Canada (F. L.).

\section{Author details}

'Department of Neuroscience, Centre for Addiction and Mental Health, Toronto, Canada. ${ }^{2}$ Brain Research Center, University of British Columbia, Vancouver, Canada. ${ }^{3}$ Department of Psychiatry, University of Toronto, Toronto, Canada. ${ }^{4}$ Department of Neuroscience, Centre for Addiction and Mental Health, Clarke Division, 250 College Street, Toronto, ON M5T 1R8, Canada.

\section{Authors' contributions}

MW carried out all experiments, with the help of SL for constructing GSTfusion proteins, HZ for AMAPR-mediated excitotoxicity assays, LP for the coimmunoprecipitation and SZ for the GST-pull down assays. FJK and YTW helped to edit the manuscript. FL supervised the study and wrote the manuscript. All authors read and approved the final manuscript.

Received: 10 March 2012 Accepted: 26 April 2012

Published: 26 April 2012

\section{References}

1. Bliss TV, Collingridge GL: A synaptic model of memory: long-term potentiation in the hippocampus. Nature 1993, 361:31-39.

2. Choi DW: Glutamate neurotoxicity and diseases of the nervous system. Neuron 1988, 1:623-634.

3. Hollmann M, Heinemann S: Cloned glutamate receptors. Annu Rev Neurosci 1994, 17:31-108.

4. Keinanen K, Wisden W, Sommer B, Werner P, Herb A, Verdoorn TA, Sakmann B, Seeburg PH: A family of AMPA-selective glutamate receptors. Science 1990, 249:556-560.

5. Boulter J, Hollmann M, O'Shea-Greenfield A, Hartley M, Deneris E, Maron C, Heinemann S: Molecular cloning and functional expression of glutamate receptor subunit genes. Science 1990, 249:1033-1037.

6. Choi DW: Calcium: still center-stage in hypoxic-ischemic neuronal death. Trends Neurosci 1995, 18:58-60. 
7. Simon RP, Swan JH, Griffiths T, Meldrum BS: Blockade of N-methyl-Daspartate receptors may protect against ischemic damage in the brain. Science 1984, 226:850-852.

8. Dos-Anjos S, Martinez-Villayandre B, Montori S, Regueiro-Purrinos MM, Gonzalo-Orden JM, Fernandez-Lopez A: Global ischemia-induced modifications in the expression of AMPA receptors and inflammation in rat brain. Brain Res 2009, 1287:20-27.

9. Elger B, Gieseler M, Schmuecker O, Schumann I, Seltz A, Huth A: Extended therapeutic time window after focal cerebral ischemia by noncompetitive inhibition of AMPA receptors. Brain Res 2006, 1085:189-194.

10. Gill R, Lodge D: Pharmacology of AMPA antagonists and their role in neuroprotection. Int Rev Neurobiol 1997, 40:197-232.

11. Gressens P, Spedding M, Gigler G, Kertesz S, Villa P, Medja F, Williamson T, Kapus G, Levay G, Szenasi G, et al: The effects of AMPA receptor antagonists in models of stroke and neurodegeneration. Eur J Pharmacol 2005, 519:58-67.

12. Matucz E, Moricz K, Gigler G, Simo A, Barkoczy J, Levay G, Harsing LG Jr, Szenasi G: Reduction of cerebral infarct size by non-competitive AMPA antagonists in rats subjected to permanent and transient focal ischemia. Brain Res 2004, 1019:210-216

13. McCarran WJ, Goldberg MP: White matter axon vulnerability to AMPA/ kainate receptor-mediated ischemic injury is developmentally regulated. J Neurosci 2007, 27:4220-4229.

14. Oguro K, Oguro N, Kojima T, Grooms SY, Calderone A, Zheng X, Bennett MV Zukin RS: Knockdown of AMPA receptor GluR2 expression causes delayed neurodegeneration and increases damage by sublethal ischemia in hippocampal CA1 and CA3 neurons. J Neurosci 1999, 19:9218-9227.

15. Pellegrini-Giampietro DE, Zukin RS, Bennett MV, Cho S, Pulsinelli WA: Switch in glutamate receptor subunit gene expression in CA1 subfield of hippocampus following global ischemia in rats. Proc Natl Acad Sci USA 1992, 89:10499-10503.

16. Peng PL, Zhong $X$, Tu W, Soundarapandian MM, Molner P, Zhu D, Lau L, Liu S, Liu F, LU Y: ADAR2-dependent RNA editing of AMPA receptor subunit GluR2 determines vulnerability of neurons in forebrain ischemia. Neuron 2006, 49:719-733.

17. Pulsinelli WA, Levy DE, Duffy TE: Regional cerebral blood flow and glucose metabolism following transient forebrain ischemia. Ann Neurol 1982, 11:499-502.

18. Schmidt-Kastner R, Freund TF: Selective vulnerability of the hippocampus in brain ischemia. Neuroscience 1991, 40:599-636.

19. Weiss JH, Sensi SL: Ca2+-Zn2+ permeable AMPA or kainate receptors: possible key factors in selective neurodegeneration. Trends Neurosci 2000, 23:365-371.

20. Yin HZ, Sensi SL, Ogoshi F, Weiss JH: Blockade of Ca2 +-permeable AMPA/kainate channels decreases oxygen-glucose deprivation-induced Zn2+ accumulation and neuronal loss in hippocampal pyramidal neurons. J Neurosci 2002, 22:1273-1279.

21. Tanaka H, Grooms SY, Bennett MV, Zukin RS: The AMPAR subunit GluR2: still front and center-stage. Brain Res 2000, 886:190-207.

22. Geiger JR, Melcher T, Koh DS, Sakmann B, Seeburg PH, Jonas P, Monyer H: Relative abundance of subunit mRNAs determines gating and $\mathrm{Ca} 2+$ permeability of AMPA receptors in principal neurons and interneurons in rat CNS. Neuron 1995, 15:193-204.

23. Greger $\mathrm{IH}$, Khatri L, Ziff EB: RNA editing at arg607 controls AMPA receptor exit from the endoplasmic reticulum. Neuron 2002, 34:759-772.

24. Jonas P, Racca C, Sakmann B, Seeburg PH, Monyer H: Differences in Ca2+ permeability of AMPA-type glutamate receptor channels in neocortical neurons caused by differential GluR-B subunit expression. Neuron 1994 , 12:1281-1289.

25. Lu W, Shi Y, Jackson AC, Bjorgan K, During MJ, Sprengel R, Seeburg PH, Nicoll RA: Subunit composition of synaptic AMPA receptors revealed by a single-cell genetic approach. Neuron 2009, 62:254-268.

26. Wenthold RJ, Petralia RS, Blahos J II, Niedzielski AS: Evidence for multiple AMPA receptor complexes in hippocampal CA1/CA2 neurons. J Neurosci 1996, 16:1982-1989.

27. Dong H, O'Brien RJ, Fung ET, Lanahan AA, Worley PF, Huganir RL: GRIP: a synaptic PDZ domain-containing protein that interacts with AMPA receptors. Nature 1997, 386:279-284.

28. Dong H, Zhang P, Song I, Petralia RS, Liao D, Huganir RL: Characterization of the glutamate receptor-interacting proteins GRIP1 and GRIP2. J Neurosci 1999, 19:6930-6941.
29. Lee SH, Liu L, Wang YT, Sheng M: Clathrin adaptor AP2 and NSF interact with overlapping sites of GluR2 and play distinct roles in AMPA receptor trafficking and hippocampal LTD. Neuron 2002, 36:661-674.

30. Nishimune A, Isaac JT, Molnar E, Noel J, Nash SR, Tagaya M, Collingridge GL, Nakanishi S, Henley JM: NSF binding to GluR2 regulates synaptic transmission. Neuron 1998, 21:87-97.

31. Osten P, Srivastava S, Inman GJ, Vilim FS, Khatri L, Lee LM, States BA, Einheber S, Milner TA, Hanson PI, Ziff EB: The AMPA receptor GluR2 C terminus can mediate a reversible, ATP-dependent interaction with NSF and alpha- and beta-SNAPs. Neuron 1998, 21:99-110.

32. Srivastava $S$, Osten $P$, Vilim FS, Khatri L, Inman G, States B, Daly C, DeSouza $S$, Abagyan R, Valtschanoff JG, et al: Novel anchorage of GluR2/3 to the postsynaptic density by the AMPA receptor-binding protein ABP. Neuron 1998, 21:581-591.

33. Wyszynski M, Valtschanoff JG, Naisbitt S, Dunah AW, Kim E, Standaert DG, Weinberg R, Sheng M: Association of AMPA receptors with a subset of glutamate receptor-interacting protein in vivo. J Neurosci 1999, 19:6528-6537.

34. Xia J, Zhang X, Staudinger J, Huganir RL: Clustering of AMPA receptors by the synaptic PDZ domain-containing protein PICK1. Neuron 1999, 22:179-187.

35. O'Brien RJ, Xu D, Petralia RS, Steward O, Huganir RL, Worley P: Synaptic clustering of AMPA receptors by the extracellular immediate-early gene product Narp. Neuron 1999, 23:309-323.

36. Saglietti L, Dequidt C, Kamieniarz K, Rousset MC, Valnegri P, Thoumine O, Beretta F, Fagni $L$, Choquet D, Sala C, et al: Extracellular interactions between GluR2 and $\mathrm{N}$-cadherin in spine regulation. Neuron 2007, 54:461-477.

37. Yamaji R, Chatani E, Harada N, Sugimoto K, Inui H, Nakano Y: Glyceraldehyde-3-phosphate dehydrogenase in the extracellular space inhibits cell spreading. Biochim Biophys Acta 2005, 1726:261-271.

38. Chuang DM, Hough C, Senatorov W: Glyceraldehyde-3-phosphate dehydrogenase, apoptosis, and neurodegenerative diseases. Annu Rev Pharmacol Toxicol 2005, 45:269-290.

39. Hara MR, Agrawal N, Kim SF, Cascio MB, Fujimuro M, Ozeki Y, Takahashi M, Cheah JH, Tankou SK, Hester LD, et al: S-nitrosylated GAPDH initiates apoptotic cell death by nuclear translocation following Siah1 binding Nat Cell Biol 2005, 7:665-674.

40. Ishitani R, Chuang DM: Glyceraldehyde-3-phosphate dehydrogenase antisense oligodeoxynucleotides protect against cytosine arabinonucleoside-induced apoptosis in cultured cerebellar neurons. Proc Natl Acad Sci USA 1996, 93:9937-9941.

41. Ishitani R, Tanaka M, Sunaga K, Katsube N, Chuang DM: Nuclear localization of overexpressed glyceraldehyde-3-phosphate dehydrogenase in cultured cerebellar neurons undergoing apoptosis. Mol Pharmacol 1998, 53:701-707.

42. Sawa A, Khan AA, Hester LD, Snyder SH: Glyceraldehyde-3-phosphate dehydrogenase: nuclear translocation participates in neuronal and nonneuronal cell death. Proc Natl Acad Sci USA 1997, 94:11669-11674.

43. lihara K, Joo DT, Henderson J, Sattler R, Taverna FA, Lourensen S, Orser BA, Roder JC, Tymianski M: The influence of glutamate receptor 2 expression on excitotoxicity in Glur2 null mutant mice. J Neurosci 2001, 21:2224-2239.

44. Zeevalk GD, Schoepp D, Nicklas WJ: Excitotoxicity at both NMDA and nonNMDA glutamate receptors is antagonized by aurintricarboxylic acid: evidence for differing mechanisms of action. J Neurochem 1995, 64:1749-1758.

45. Goldberg MP, Choi DW: Combined oxygen and glucose deprivation in cortical cell culture: calcium-dependent and calcium-independent mechanisms of neuronal injury. J Neurosci 1993, 13:3510-3524.

46. Ying HS, Weishaupt JH, Grabb M, Canzoniero LM, Sensi SL, Sheline CT, Monyer $\mathrm{H}$, Choi DW: Sublethal oxygen-glucose deprivation alters hippocampal neuronal AMPA receptor expression and vulnerability to kainate-induced death. J Neurosci 1997, 17:9536-9544.

47. Carroll RC, Beattie EC, Xia H, Luscher C, Altschuler Y, Nicoll RA, Malenka RC, von Zastrow M: Dynamin-dependent endocytosis of ionotropic glutamate receptors. Proc Natl Acad Sci USA 1999, 96:14112-14117.

48. Lin JW, Ju W, Foster K, Lee SH, Ahmadian G, Wyszynski M, Wang YT, Sheng M: Distinct molecular mechanisms and divergent endocytotic pathways of AMPA receptor internalization. Nat Neurosci 2000, 3:1282-1290.

49. Man HY, Lin JW, Ju WH, Ahmadian G, Liu L, Becker LE, Sheng M, Wang $Y T$ : Regulation of AMPA receptor-mediated synaptic transmission by clathrin-dependent receptor internalization. Neuron 2000, 25:649-662.

50. Pei L, Lee FJ, Moszczynska A, Vukusic B, Liu F: Regulation of dopamine D1 receptor function by physical interaction with the NMDA receptors. $J$ Neurosci 2004, 24:1149-1158. 
51. Sensi SL, Yin HZ, Carriedo SG, Rao SS, Weiss JH: Preferential Zn2+ influx through Ca2 + -permeable AMPA/kainate channels triggers prolonged mitochondrial superoxide production. Proc Natl Acad Sci USA 1999, 96:2414-2419.

52. Sensi SL, Ton-That D, Sullivan PG, Jonas EA, Gee KR, Kaczmarek LK, Weiss JH: Modulation of mitochondrial function by endogenous $\mathrm{Zn} 2+$ pools. Proc Natl Acad Sci USA 2003, 100:6157-6162.

53. Medvedeva YV, Lin B, Shuttleworth CW, Weiss JH: Intracellular Zn2+ accumulation contributes to synaptic failure, mitochondrial depolarization, and cell death in an acute slice oxygen-glucose deprivation model of ischemia. J Neurosci 2009, 29:1105-1114.

54. Jiang D, Sullivan PG, Sensi SL, Steward O, Weiss JH: Zn(2+) induces permeability transition pore opening and release of pro-apoptotic peptides from neuronal mitochondria. J Biol Chem 2001, 276:47524-47529.

55. Bossy-Wetzel E, Talantova MV, Lee WD, Scholzke MN, Harrop A, Mathews E, Gotz T, Han J, Ellisman MH, Perkins GA, Lipton SA: Crosstalk between nitric oxide and zinc pathways to neuronal cell death involving mitochondrial dysfunction and p38-activated K+ channels. Neuron 2004, 41:351-365.

56. Kwak S, Weiss JH: Calcium-permeable AMPA channels in neurodegenerative disease and ischemia. Curr Opin Neurobiol 2006, 16:281-287.

57. Liu B, Liao M, Mielke JG, Ning K, Chen Y, Li L, El-Hayek YH, Gomez E, Zukin RS, Fehlings MG, Wan Q: Ischemic insults direct glutamate receptor subunit 2-lacking AMPA receptors to synaptic sites. J Neurosci 2006, 26:5309-5319.

58. Soundarapandian MM, Tu WH, Peng PL, Zervos AS, Lu Y: AMPA receptor subunit GluR2 gates injurious signals in ischemic stroke. Mol Neurobiol 2005, 32:145-155.

59. Spaethling JM, Klein DM, Singh P, Meaney DF: Calcium-permeable AMPA receptors appear in cortical neurons after traumatic mechanical injury and contribute to neuronal fate. J Neurotrauma 2008, 25:1207-1216.

60. Anzai T, Tsuzuki K, Yamada N, Hayashi T, Iwakuma M, Inada K, Kameyama K, Hoka S, Saji M: Overexpression of Ca2 + -permeable AMPA receptor promotes delayed cell death of hippocampal CA1 neurons following transient forebrain ischemia. Neurosci Res 2003, 46:41-51.

61. Liu S, Lau L, Wei J, Zhu D, Zou S, Sun HS, Fu Y, Liu F, Lu Y: Expression of Ca (2+)-permeable AMPA receptor channels primes cell death in transient forebrain ischemia. Neuron 2004, 43:43-55.

62. Li SY, Ni JH, Xu DS, Jia HT: Down-regulation of GluR2 is associated with $\mathrm{Ca} 2+-$ dependent protease activities in kainate-induced apoptotic cell death in cultured [correction of culturd] rat hippocampal neurons. Neurosci Lett 2003, 352:105-108

63. Dittmann K, Mayer C, Kehlbach R, Rodemann HP: Radiation-induced caveolin-1 associated EGFR internalization is linked with nuclear EGFR transport and activation of DNA-PK. Mol Cancer 2008, 7:69

64. Liao HJ, Carpenter G: Role of the Sec61 translocon in EGF receptor trafficking to the nucleus and gene expression. Mol Biol Cell 2007, 18:1064-1072

65. Doucet JP, Tuana BS: Identification of low molecular weight GTP-binding proteins and their sites of interaction in subcellular fractions from skeletal muscle. J Biol Chem 1991, 266:17613-17620.

66. Fuchtbauer A, Jockusch BM, Leberer E, Pette D: Actin-severing activity copurifies with phosphofructokinase. Proc Natl Acad Sci USA 1986, 83:9502-9506.

67. Glaser PE, Gross RW: Rapid plasmenylethanolamine-selective fusion of membrane bilayers catalyzed by an isoform of glyceraldehyde-3phosphate dehydrogenase: discrimination between glycolytic and fusogenic roles of individual isoforms. Biochemistry 1995, 34:12193-12203.

68. Huitorel P, Pantaloni D: Bundling of microtubules by glyceraldehyde-3phosphate dehydrogenase and its modulation by ATP. Eur J Biochem 1985, 150:265-269.

69. Ikemoto A, Bole DG, Ueda T: Glycolysis and glutamate accumulation into synaptic vesicles. Role of glyceraldehyde phosphate dehydrogenase and 3-phosphoglycerate kinase. J Biol Chem 2003, 278:5929-5940.

70. Robbins AR, Ward RD, Oliver C: A mutation in glyceraldehyde 3-phosphate dehydrogenase alters endocytosis in CHO cells. J Cell Biol 1995, 130:1093-1104.

71. Tisdale EJ: Glyceraldehyde-3-phosphate dehydrogenase is required for vesicular transport in the early secretory pathway. J Biol Chem 2001, 276:2480-2486.

72. Chen RW, Saunders PA, Wei H, Li Z, Seth P, Chuang DM: Involvement of glyceraldehyde-3-phosphate dehydrogenase (GAPDH) and p53 in neuronal apoptosis: evidence that GAPDH is upregulated by $\mathrm{p} 53$. J Neurosci 1999, 19:9654-9662.

73. Lakkaraju A, Dubinsky JM, Low WC, Rahman YE: Neurons are protected from excitotoxic death by p53 antisense oligonucleotides delivered in anionic liposomes. J Biol Chem 2001, 276:32000-32007.

74. Sakhi S, Bruce A, Sun N, Tocco G, Baudry M, Schreiber SS: p53 induction is associated with neuronal damage in the central nervous system. Proc Natl Acad Sci USA 1994, 91:7525-7529.

75. Uberti D, Belloni M, Grilli M, Spano P, Memo M: Induction of tumoursuppressor phosphoprotein $\mathrm{p} 53$ in the apoptosis of cultured rat cerebellar neurones triggered by excitatory amino acids. Eur I Neurosci 1998, 10:246-254.

76. Miller FD, Pozniak CD, Walsh GS: Neuronal life and death: an essential role for the p53 family. Cell Death Differ 2000, 7:880-888.

77. Brooks CL, Gu W: Ubiquitination, phosphorylation and acetylation: the molecular basis for p53 regulation. Curr Opin Cell Biol 2003, 15:164-171.

78. Colbourne F, Grooms SY, Zukin RS, Buchan AM, Bennett MV: Hypothermia rescues hippocampal CA1 neurons and attenuates down-regulation of the AMPA receptor GluR2 subunit after forebrain ischemia. Proc Natl Acad Sci USA 2003, 100:2906-2910.

79. Hemmen TM, Lyden PD: Induced hypothermia for acute stroke. Stroke 2007, 38:794-799.

80. Linares G, Mayer SA: Hypothermia for the treatment of ischemic and hemorrhagic stroke. Crit Care Med 2009, 37:S243-\$249.

81. Poli S, Veltkamp R: Oxygen therapy in acute ischemic stroke experimental efficacy and molecular mechanisms. Curr Mol Med 2009, 9:227-241.

82. Burns TC, Verfaillie CM, Low WC: Stem cells for ischemic brain injury: a critical review. J Comp Neurol 2009, 515:125-144.

83. Ohab JJ, Fleming S, Blesch A, Carmichael ST: A neurovascular niche for neurogenesis after stroke. J Neurosci 2006, 26:13007-13016.

84. Gutierrez M, Merino JJ, de Lecinana MA, Diez-Tejedor E: Cerebral protection, brain repair, plasticity and cell therapy in ischemic stroke. Cerebrovasc Dis 2009, 27(Suppl 1):177-186.

85. Lee FJ, Xue S, Pei L, Vukusic B, Chery N, Wang Y, Wang YT, Niznik HB, Yu XM, Liu F: Dual regulation of NMDA receptor functions by direct protein-protein interactions with the dopamine D1 receptor. Cell 2002, 111:219-230.

86. Liu F, Wan Q, Pristupa ZB, Yu XM, Wang YT, Niznik HB: Direct proteinprotein coupling enables cross-talk between dopamine D5 and gammaaminobutyric acid A receptors. Nature 2000, 403:274-280.

87. Zou S, Li L, Pei L, Vukusic B, Van Tol HH, Lee FJ, Wan Q, Liu F: Proteinprotein coupling/uncoupling enables dopamine D2 receptor regulation of AMPA receptor-mediated excitotoxicity. J Neurosci 2005, 25:4385-4395.

88. Hara MR, Thomas B, Cascio MB, Bae Bl, Hester LD, Dawson VL, Dawson TM, Sawa A, Snyder SH: Neuroprotection by pharmacologic blockade of the GAPDH death cascade. Proc Natl Acad Sci USA 2006, 103:3887-3889.

doi:10.1186/1756-6606-5-13

Cite this article as: Wang et al:: Direct interaction between GluR2 and GAPDH regulates AMPAR-mediated excitotoxicity. Molecular Brain 2012 5:13.

\section{Submit your next manuscript to BioMed Central and take full advantage of:}

- Convenient online submission

- Thorough peer review

- No space constraints or color figure charges

- Immediate publication on acceptance

- Inclusion in PubMed, CAS, Scopus and Google Scholar

- Research which is freely available for redistribution 